\title{
Identification of glacial meltwater runoff in a karstic environment and its implication for present and future water availability
}

\author{
D. Finger ${ }^{1,2, *}$, A. Hugentobler ${ }^{1,2}$, M. Huss ${ }^{3}$, A. Voinesco ${ }^{3,4}$, H. Wernli ${ }^{1,2}$, D. Fischer $^{1,2}$, E. Weber ${ }^{5}$, P.-Y. Jeannin ${ }^{5}$, \\ M. Kauzlaric ${ }^{1,2}$, A. Wirz ${ }^{1,2}$, T. Vennemann ${ }^{6}$, F. Hüsler ${ }^{1,2}$, B. Schädler ${ }^{1,2}$, and R. Weingartner ${ }^{1,2}$ \\ ${ }^{1}$ Institute of Geography, University of Bern, Bern, Switzerland \\ ${ }^{2}$ Oeschger Centre for Climate Change Research, University of Bern, Bern, Switzerland \\ ${ }^{3}$ Department of Geosciences, University of Fribourg, Fribourg, Switzerland \\ ${ }^{4}$ Institute of Geography, University of Neuchatel, Neuchatel, Switzerland \\ ${ }^{5}$ Swiss Institute of Speleology and Karst-Research, La Chaux-de-Fonds, Switzerland \\ ${ }^{6}$ Institute of Earth Sciences, University of Lausanne, Lausanne, Switzerland \\ *now at: Institute of Geography, University of Zurich, Zurich, Switzerland
}

Correspondence to: D. Finger (fingerd@gmx.net)

Received: 11 January 2013 - Published in Hydrol. Earth Syst. Sci. Discuss.: 6 March 2013

Revised: 4 July 2013 - Accepted: 9 July 2013 - Published: 20 August 2013

\begin{abstract}
Glaciers all over the world are expected to continue to retreat due to the global warming throughout the 21 st century. Consequently, future seasonal water availability might become scarce once glacier areas have declined below a certain threshold affecting future water management strategies. Particular attention should be paid to glaciers located in a karstic environment, as parts of the meltwater can be drained by underlying karst systems, making it difficult to assess water availability. In this study tracer experiments, karst modeling and glacier melt modeling are combined in order to identify flow paths in a high alpine, glacierized, karstic environment (Glacier de la Plaine Morte, Switzerland) and to investigate current and predict future downstream water availability. Flow paths through the karst underground were determined with natural and fluorescent tracers. Subsequently, geologic information and the findings from tracer experiments were assembled in a karst model. Finally, glacier melt projections driven with a climate scenario were performed to discuss future water availability in the area surrounding the glacier. The results suggest that during late summer glacier meltwater is rapidly drained through well-developed channels at the glacier bottom to the north of the glacier, while during low flow season meltwater enters into the karst and is drained to the south. Climate change projections with the glacier melt model reveal that by the end of the century glacier melt will be significantly reduced in the summer, jeopardizing water availability in glacier-fed karst springs.
\end{abstract}

\section{Introduction}

Global warming has led to a drastic reduction of glacier volume in many mountain regions of the world (Dyurgerov and Meier, 2000; Kaser et al., 2006; Gardner et al., 2013). This reduction will subsequently affect glacier melt runoff, affecting downstream water resources (Farinotti et al., 2012; Finger et al., 2012). In alpine regions this will affect valuable water usages such as hydropower production (Finger et al., 2012; SGHL, 2011), irrigated agriculture, snow production and drinking water (Reynard, 2000; FOEN, 2012). Predictions are complex, as meltwater drainage from the glaciers is subject to diurnal variability (Schuler et al., 2004) and may evolve during the melting season due to enhanced melting (Covington et al., 2012) and glacial lake outbursts (Werder et al., 2009). In karstic environments such projections become even more difficult as runoff paths are underground and therefore difficult to observe and assess (Bonacci et al., 2006; Siemers and Dreybrodt, 1998). In many situations the proportion of water from a glacier to a karst spring is unknown, and, conversely, the number of springs fed by a glacier is difficult to estimate (Jobard and Dzikowski, 2006; Gremaud et al., 2009; Gremaud and Goldscheider, 2010).

Perhaps the first comprehensive scientific treatise on glaciers, underground drainage systems and downstream rivers, was drafted by the Icelandic glaciologist Sveinn Pálsson in the 18th century (Pálsson, 2004). By the second 
half of the 20th century, Smart et al. (1983) started to investigate the relationship between alpine glaciers and connected aquifers more thoroughly, drilling boreholes in the glacier and performing dye tracers experiments (Smart, 1983a, b, 1996). Subsequent works along this line lead to a comprehensive process understanding described by Hubbard and Nienow (1997) and later on by Clarke (2005). Flowers et al. (2003) demonstrated the interaction of glaciergroundwater below the Pleistocene ice shields in a numerical model, and Marechal et al. (1999) investigated the cooling effect of the alpine massif due to meltwater infiltration. Finally, Skoglund et al. (2010) demonstrated that glacier ice contact can also impact on the evolution of subglacial karst systems.

This research is of major importance as downstream settlements and ecosystems are directly dependent on water resources originating either directly from the glacier melt or from karst springs fed with glacier meltwater. It is essential for water managers to understand the origin of water resources in order to adapt adequate water management strategies to cope with the impacts of climate change on water resources (FOEN, 2012). A drastic decrease in glacier volume can lead to a desiccation of karst springs fed by water from glaciers. In remote mountain areas this could lead to water shortages, as replacement water would have to be transported from far away to regions lacking glacial meltwater. Recent research has been focusing on assessing water resources from karstic environment using karst models (Doerfliger et al., 1999; Butscher and Huggenberger, 2009; Jeannin et al., 2013), artificial tracer experiments (Goldscheider et al., 2008) and chemical and isotopic composition in runoff water (Grasso and Jeannin, 2002). Nevertheless, to assess current and future water resources, it is necessary to combine the three techniques and assemble the results in an illustrative karst model. Hence, an integrative assessment of karst modeling, natural and artificial tracer experiments and climate change projections of glacier retreat allows assessing present and future water resources.

A typical example of a karstic environment in the Alpine region is the Glacier de la Plaine Morte (PM) in the Bernese Oberland, Switzerland (Maire, 1977; Wildberger, 1979). In this study we present a combination of natural and fluorescent tracer investigations, karst modeling and glacier melt modeling in order to identify current and future pathways of glacier meltwater through the karst to downstream areas of interest. For this purpose a 3-D karst model was established using topographic and geological information in order to design tracer experiments that allow determining the melt pathways. During and after tracer injection on the glacier, meteorological parameters, discharge and tracer concentrations were measured at all relevant locations. Subsequently, the karst model was validated and revised with the results of the tracer experiments. In order to assess future water availability, climate change projections of glacial meltwater were performed using a dynamic glacier model. The study concludes by discussing probable trends in water resources at designated karst springs around Glacier de la Plaine Morte. Overall, our study is in line with the ongoing research summarized by Leibundgut (2009), combining tracer experiments with glacier modeling, karst modeling, isotopic observations and satellite-derived snow cover observations. Although the specific results are only valid for the presented case study, the proceeding and the general conclusions discussed in this paper can apply to any karstic mountain area.

\section{Study site}

The Glacier de la Plaine Morte in the Bernese Oberland was selected for this study, as it represents a typical example of an alpine karstic environment, where downstream ecosystems and economic uses depend on glacial and rainfall runoff. The main characteristics of the study site are summarized below.

\subsection{Glacier de la Plaine Morte}

The Glacier de la Plaine Morte is a large plateau glacier that is situated in southern Switzerland on the main water divide between the Rhine and Rhone at the border of the cantons Bern and Valais (Fig. 1a and b). The glacier is characterized by an almost $5 \mathrm{~km}$ wide plateau at an altitude ranging between 2700 and $2800 \mathrm{~m}$ a.s.l., and a small and narrow glacier tongue, also called Retzligletscher, descending in northern direction (Fig. 1c). Since 1985 the glacier has been completely snow-free during summer due to its low elevation. This is important, as in the absence of accumulation phases the glacier is expected to disappear within the present century. Furthermore, a snow-free glacier features lower surface albedo and thus enhances the effects of direct solar radiation on glacier melt (Bühlmann, 2011; Paul et al., 2005). In 2011, the glacier covered a total area of approximately $8 \mathrm{~km}^{2}$ and reached thicknesses of more than $200 \mathrm{~m}$ (Voinesco, 2012). The total ice volume of the Plaine Morte is $0.82 \mathrm{~km}^{3}$ (in 2011), which corresponds to $1-1.5 \%$ of the total glacier ice volume in the Swiss Alps (Farinotti et al., 2009).

The ski resort Crans-Montana (CM) is situated south of the glacier. Water requirements in Crans-Montana peak during summer due to irrigation demands and in winter due to snowmaking demands (Reynard and Bonriposi, 2012). North of the glacier, agricultural areas in the Simmen valley depend on precipitation and meltwater from the Plaine Morte region. In the Simmen valley water demands are similar to the Crans-Montana region, as water is being pumped from the river Simme to surrounding ski resorts for snow production in winter and for irrigation to agricultural areas in the valley bottom in the summer. Consequently, a reduction of water availability might intensify and sharpen the political discussions about water uses for irrigational purposes, snow production, hydropower production and drinking water (Reynard and Bonriposi, 2012). 


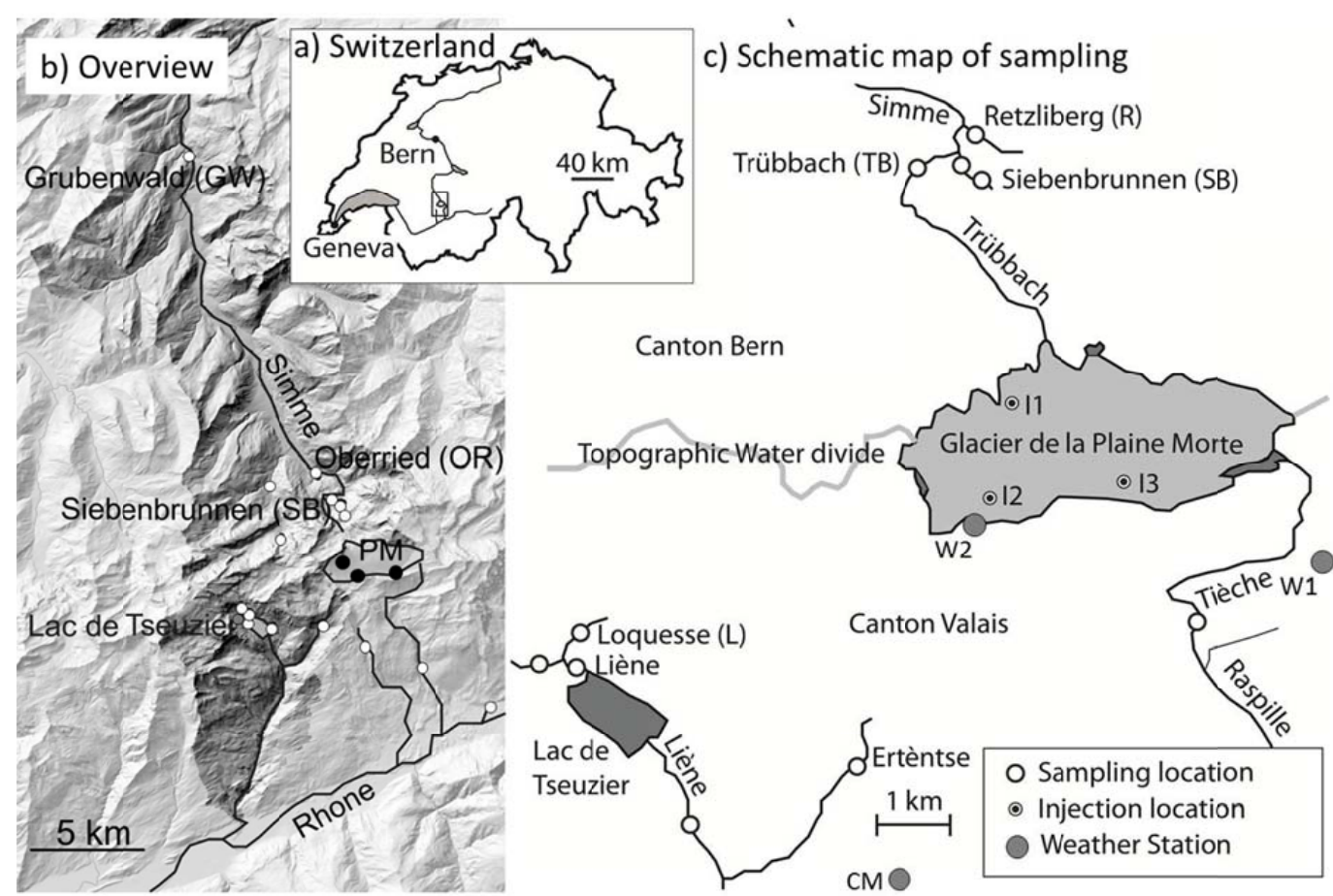

Fig. 1. Overview of the study site including the surroundings of the Glacier de la Plaine Morte (PM). (a) locates the study area with a square in Switzerland, (b) gives a topographic overview of the two valleys to the north and south of the PM (darkened area delimits topographic watershed of the Simme and the Liène); (c) illustrates schematically sampling locations around PM. Dark grey areas on the border of PM illustrate temporary glacier lakes.

\subsection{Geologic and hydrologic characteristics of the study site}

Being part of the Helvetic nappes, the geology surrounding the Plaine Morte is mainly composed of limestone (Fig. 2). As is the case for most nappes, the limestones are aligned in parallel to the topography (i.e., striking the southeast flank of the Crans-Montana region, sub-horizontal below the Glacier de la Plaine Morte and steep towards northwest). In the front of the nappes a reversed dip can be expected. In the investigated area three main nappes lying on top of the eastern end of the Aare Massif have been identified (Badoux, 1945; Wildberger, 1979; Gabus et al., 2008). The Doldenhorn nappe is the lowest one with a thick series of limestone separated by some shaly layers. The Gellihorn nappe is much thinner and of limited significance for the present work. The Wildhorn nappe is the most relevant one for the present study because most of the outcropping rocks belong to this upper unit. It encloses two main karstified layers forming two karst aquifers: the Urgonian limestone (locally also called Schrattenkalk-Formation) and the Malm limestone (Fig. 2). The upper limestone drains most of the infiltration waters. Marls and shales represent more or less impermeable barriers between the two main karst aquifers.

The karstic area drains most of the precipitation and meltwater, and a series of karst springs have been identified all around the area, on both sides of the water divide (Wildberger, 1979). The catchment areas of the respective springs are not well delineated, making it difficult to assess water availability on each side. Indeed, discharge from snow and ice melt, as well as rainfall runoff, is characterized by different mechanisms depending on upstream catchment characteristics: (i) water storage in the glacier and the snow fields, (ii) rapid subsurface flow under gravel-covered soil, (iii) slow flow in fertile agricultural soil, (iv) retention in natural swamps, (v) storage in natural and artificial lakes, (vi) seasonal streams running on the glacier, primarily swallowed in "moulins" and crevasses partly connected to sinkholes underneath the glacier, and (vii) a well-developed karst system that drains meltwater to karstic springs at lower elevations.

At altitudes above $1500 \mathrm{~m}$ a.s.l. the stream network is poorly developed, showing a high proportion of screes and karsts (Maire, 1978). This region corresponds to the water divide between Rhone and Rhine rivers, and also between two cantons Bern and Valais (Fig. 1b). The Glacier de la Plaine Morte represents a huge water reservoir that has been continuously declining due to warmer temperatures during recent decades. The exact mapping of mountain creeks in this area is impossible as water flow paths are on the surface as well as in the karst. Karst water is drained to numerous karst springs surrounding the glacier at lower elevation, such as the Siebenbrunnen (SB) spring in the north and the Loquesse 


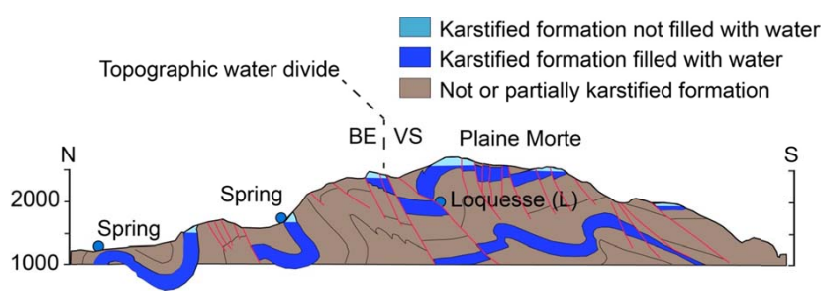

Fig. 2. Geological cross section along Oberried, Siebenbrunnen and Lac de Tseuzier. Urgonian limestone and Malm limestone karstic aquifers are highlighted in blue. The Loquesse spring (L) is projected according to geology. Modified after Wildberger (1979).

(L) spring in the southwest (Fig. 1c). Accordingly, discharge is highly variable and depends on the above-mentioned properties.

Surface torrents and rivers mostly occur below $1500 \mathrm{~m}$ a.s.l. with numerous mountain creeks, all emerging from karst springs. The Tièche River, coming from the southeastern part of the Plaine Morte, and the Trübbach, emerging from the northern end of the Plaine Morte, are exceptions. In particular Trübbach is primarily fed with glacier meltwater with only few small karst springs feeding into the river. Accordingly, in absence of local precipitation events, Trübbach represents the glacier outflow very well. The Trübbach enters a few hundred meters downstream of the Siebenbrunnen spring into the Simme river, which drains the water to the north, passing the village of Oberried (OR) and Grubenwald (GW), both sampling locations during the tracer experiments.

The permeable nature of the karst massif explains the restricted number of lakes in this periglacial landscape. The main exception is the Lac de Tseuzier (LT), which is an artificial hydropower reservoir operated by the Lienne SA hydropower company. The other lakes are small and mostly temporary. On the southern side of the Plaine Morte, the natural drainage patterns are additionally deviated by irrigation channels along the flanks of the mountains to divert water for agricultural use (Crook and Jones, 1999).

\section{Methods and data}

In order to identify and analyze the flow paths of glacier meltwater in the Plaine Morte area and discuss possible effects of climate change on water resources, a variety of measurements and modeling tasks, were performed. In a first step all geologic and hydrologic information was assembled in a karst model in order to set up an adequate strategy for natural and artificial tracer investigations. Subsequently, artificial tracer experiments, as well as isotopic natural tracer measurements in the runoff were performed in order to assess the primary pathways of meltwater. Furthermore, snow cover data derived from satellite imagery and meteorological data from three weather stations were available for the entire investigation period. Complementary discharge gauging stations were installed at relevant locations during the tracer experiments. Finally, the future meltwater generation was estimated with a glacier melt and retreat model driven with climate scenarios forced with A1B emission scenarios. All data sets available for this study are summarized in Table 1 , and details of data collections are described below.

\subsection{Karst model}

All existing geological information (Sect. 2.2 and Table 1) was assembled into a 3-D geological model using the software package CINEMA 4D (MAXON Computer GmbH) in order to identify relevant sampling sites for artificial tracer experiments. During this process local inconsistencies from the different geologic maps were corrected. For this purpose information from existing literature was considered in order to incorporate a maximum of available information. This model was built according to the "KARSYS approach" (Jeannin et al., 2013), which is being developed within the framework of the Swisskarst project (http://swisskarst.ch), part of the NRP (National Research Programme) 61.

For the construction of the geological model, three data sources were used: (i) four geological maps at a scale of $1: 25000$ (Swisstopo); (ii) 15 geological cross sections and (iii) a digital elevation model (DEM) with $25 \mathrm{~m}$ gridding (Swisstopo).

Once the geometry of the main aquifer (Urgonian limestone) was defined, the main karst springs were introduced into the 3-D model. Due to high hydraulic conductivity of karst conduits, it can be assumed that the hydraulic gradient upstream from the springs is lower than $1 \%$. Therefore, the volume of the aquifer located below the level of the springs can be considered as the phreatic part of the karst aquifer. During high water conditions the top of the phreatic zone may rise up by dozens or even hundreds of meters (Wildberger et al., 2001). Nevertheless, unexplored folds and faults may also create reservoir structures and phreatic conditions above the level of the springs.

In Fig. 3 an illustration of the assembled information of the karst model is given. The structure of the karst model is tilted towards the west making the intersection between topography and geology very complex. Nevertheless, the 3-D karst model is an ideal tool to investigate karst flow paths in such a complex setting and develop a hypothesis for successful tracer experiment setups (Fig. 3). It allows building the geometry of the main aquifers in 3-D and applying some basic principles of karst hydraulics (KARSYS approach). The final model obtained using also the results from the tracer experiments is presented in the result section of this study. 
Table 1. Overview of available data and observations.

\begin{tabular}{|c|c|c|c|c|c|}
\hline \multicolumn{6}{|c|}{ Karstic 3-D model } \\
\hline \multicolumn{2}{|c|}{ Map/information } & \multicolumn{2}{|l|}{ resolution } & \multicolumn{2}{|r|}{ Source } \\
\hline $\begin{array}{r}\mathrm{Ge} \\
15 \text { geolog }\end{array}$ & $\begin{array}{l}\text { ologic map } \\
\text { ical cross sections } \\
\text { DEM }\end{array}$ & \multicolumn{2}{|c|}{$\begin{array}{c}1: 25000 \\
1: 25000 / 1: 50000 \\
25 \mathrm{~m} \times 25 \mathrm{~m}\end{array}$} & \multicolumn{2}{|c|}{$\begin{array}{c}\text { Swiss geologic survey } \\
\text { Available at ISSKA } \\
\text { Swisstopo }\end{array}$} \\
\hline \multicolumn{6}{|c|}{ Meteo and snow cover data } \\
\hline Parameter & Location $^{\mathrm{a}}$ & $\begin{array}{l}\text { Sampling } \\
\text { period }\end{array}$ & Unit & $\begin{array}{l}\text { Frequency of } \\
\text { sampling }\end{array}$ & Source \\
\hline $\begin{array}{l}\text { Snow height and temperature } \\
\text { Temperature } \\
\text { Temperature, precipitation } \\
\text { snow cover area ratio }\end{array}$ & $\begin{array}{l}\mathrm{W} 1 \\
\mathrm{~W} 2 \\
\mathrm{CM}\end{array}$ & $\begin{array}{l}2011-2012 \\
2011-2012 \\
2011-2012 \\
2001-2012\end{array}$ & $\begin{array}{l}{ }^{\circ} \mathrm{cm} ;{ }^{\circ} \mathrm{C} \\
{ }^{\circ} \mathrm{C} ; \mathrm{mm} \\
-\end{array}$ & $\begin{array}{l}\text { daily } \\
\text { daily } \\
\text { daily } \\
\text { daily }\end{array}$ & $\begin{array}{l}\text { SLF }^{b} \\
\text { CMA }^{b} \\
\text { MeteoSwiss } \\
\text { Hall et al. (2002) }\end{array}$ \\
\hline \multicolumn{6}{|c|}{ Tracer experiment } \\
\hline $\begin{array}{l}\text { Water sampling (APEG) } \\
\text { discharge }\end{array}$ & $\begin{array}{l}\text { GW, OR, SB, R, SB, TB, L and more } \\
\text { LT, OR, TB, SB, GW }\end{array}$ & $\begin{array}{l}22 \text { Aug 2011-31 Aug } 2011 \\
1993-2012\end{array}$ & $\begin{array}{l}\mathrm{mg} \mathrm{m}^{-3} \\
\mathrm{~m}^{3} \mathrm{~s}^{-1}\end{array}$ & $\begin{array}{l}1,4,6,8,12,24 \mathrm{~h} \\
5 \mathrm{~min} / \text { daily }\end{array}$ & $\begin{array}{l}\text { Authors/FOEN } \\
\text { FOEN/authors/Lienne SA }\end{array}$ \\
\hline \multicolumn{6}{|c|}{ Glacier melt modeling } \\
\hline Data set & Location $^{\mathrm{a}}$ & $\begin{array}{l}\text { Sampling } \\
\text { period }\end{array}$ & Unit & $\begin{array}{l}\text { Frequency of } \\
\text { sampling }\end{array}$ & Source \\
\hline $\begin{array}{l}\text { Mass balance } \\
\text { Digital elevation model } \\
\text { Ice thickness } \\
\text { Climate scenarios }\end{array}$ & $\begin{array}{l}\text { PM } \\
\text { PM } \\
\text { PM }\end{array}$ & $\begin{array}{l}2010 / 2011 \\
1956 \text { and } 2005 \\
2010 \\
2010-2100\end{array}$ & $\begin{array}{l}\text { mm w. eqv. } \\
\mathrm{m}\end{array}$ & 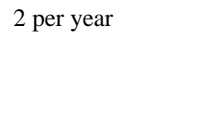 & $\begin{array}{l}\text { Authors } \\
\text { Authors } \\
\text { Authors } \\
\text { Frei (2007) }\end{array}$ \\
\hline \multicolumn{6}{|c|}{$\begin{array}{l}{ }^{a} \mathrm{LT}=\mathrm{Lac} \text { de Tseuzier, } \mathrm{CM}=\text { Crans-Montana, } \mathrm{GW}=\text { Grubenwald, } \mathrm{OR}=\text { Oberried, } \mathrm{SB}=\text { Siebenbrunnen, } \mathrm{TB}=\text { Trübbach, } \mathrm{L}=\mathrm{Loquesse}, \mathrm{PM}=\mathrm{Plaine} \text { Morte, } \mathrm{W} 1=\text { weather } \\
\text { station operated by SLF, W2 = weather station operated by CMA. } \\
\text { b SLF = Institute for Snow and Avalanche Research, Davos; CMA = Sensalpin on behalf of Remontées mécaniques de Crans-Montana. } \\
\text { c Over } 30 \text { karst springs were sampled during tracer experiments. Locations where no tracer was detected are not named and only visualized in Fig. } 1 . \\
\text { d At GW and OR the FOEN operates stationary gauging stations; discharge at other locations was estimated with pressure sensors converted to continuous ( } 5 \text { min resolution) } \\
\text { discharge time series with periodic discharge measurements using the salt method (Hugentobler, 2013). Daily discharge into Lac de Tseuzier is computed from reservoir level } \\
\text { and drainage by Lienne SA. }\end{array}$} \\
\hline
\end{tabular}

\subsection{Monitoring of meteorological and snow cover conditions}

Meteorological conditions during the tracer experiments were available from three weather stations located at W1, W2 and CM (Fig. 1) operated by the Institute for Snow and Avalanche Research (SLF), by the Remontée mécaniques de Crans-Montana (CMA) and the Federal Office of Meteorology and Climatology (MeteoSwiss), respectively. The ratio of snow cover area within the watershed of the Simme and the Liène (Fig. 1) was derived from daily satellite images recorded by the moderate resolution imaging spectroradiometer (MODIS) (Hall et al., 2002). Similarly to Finger et al. (2011) and Hüsler (2012), the MODIS product MOD10A1.5 (see http://nsidc.org/) was used in this study. Total discharge into Lac de Tseuzier computed from water release and lake level recordings was provided by Lienne SA; discharge at GW and OR was made available by the Swiss Federal Office of Environment (FOEN). At Trübbach (TB), $\mathrm{SB}$ and $\mathrm{L}$ continuous discharge was estimated with pressure sensors converted to continuous discharge time series based on periodic discharge measurements using the salt method as described by Hugentobler (2013).
Table 2. Overview of the tracer injections.

\begin{tabular}{llll}
\hline Date and time $^{\mathrm{a}}$ & Tracer & Amount & Location of injection $^{\mathrm{b}}$ \\
\hline $\begin{array}{l}\text { 22 August 2011, } \\
\text { 13:30 (S2) }\end{array}$ & Eosine & $36 \mathrm{~kg}$ & $\mathrm{I} 1(604202 / 137013)$ \\
$\begin{array}{l}\text { 22 August 2011, } \\
\text { 12:45(S2) }\end{array}$ & Duasyn & $38.4 \mathrm{~kg}$ & $\mathrm{I} 2(604871 / 136339)$ \\
$\begin{array}{l}\text { 22 August 2011, } \\
\text { 11:40(S2) }\end{array}$ & Uranine & $12 \mathrm{~kg}$ & $\mathrm{I} 3(607002 / 136471)$ \\
$\begin{array}{l}\text { 6 August 2012, } \\
\text { 11:05(S1) }\end{array}$ & Uranine & $8 \mathrm{~kg}$ & $\mathrm{I} 2(604262 / 136376)$ \\
$\begin{array}{l}\text { 2 September 2012, } \\
11: 00(\mathrm{~S} 3)\end{array}$ & Uranine & $4 \mathrm{~kg}$ & $\mathrm{I} 2(604262 / 136376)$ \\
\hline
\end{tabular}

${ }^{\text {a }} \mathrm{S} 1, \mathrm{~S} 2$ and S3 represent typical situations during summer season as outlined in the discussion section.

${ }^{\mathrm{b}}$ Locations are given in Swiss grid system CH1903 and visualized in Fig. 1.

\subsection{Tracer experiments}

In order to identify flow pathways of meltwater from the Plaine Morte, five tracer experiments were conducted using three different fluorescent tracers (Table 2). The objective of these experiments was to assess the spatial contribution of meltwater from different glacier regions as well as the seasonal evolution of melt drainage due to changing hydrometeorological conditions. 
Table 3. Overview of tracer recovery in karst and surface runoffs after the injections in August 2011.

\begin{tabular}{|c|c|c|c|c|c|}
\hline & Abbrev. & & Duasyn [kg] & Uranine $[\mathrm{kg}]$ & Eosine $[\mathrm{kg}]$ \\
\hline Injection location & & & South (I2) & Southeast (I3) & North (I1) \\
\hline Total injected amount & & & 38.4 & 12 & 36 \\
\hline Location (type) & & Canton & & acer recovery $[\mathrm{kg}$ & \\
\hline Oberried (surface) & OR & $\mathrm{BE}$ & 12.5 & 8 & 36.7 \\
\hline Grubenwald (surface) & GW & $\mathrm{BE}$ & 8.4 & 9.5 & 41.9 \\
\hline Retzliberg (karst) & $\mathrm{R}$ & $\mathrm{BE}$ & traces & traces & traces \\
\hline Siebenbrunnen (karst) & SB & $\mathrm{BE}$ & traces & traces & traces \\
\hline \multirow[t]{2}{*}{ Loquesse (karst) } & $\mathrm{L}$ & VS & $9.3 \pm 0.1^{\mathrm{a}}$ & nothing & nothing \\
\hline & & & \multicolumn{3}{|c|}{ Mean flow velocity $\left[\mathrm{km} \mathrm{h}^{-1}\right]^{\mathrm{b}}$} \\
\hline Trübbach (surface) & TB & $\mathrm{BE}$ & 2.4 & 3.0 & - \\
\hline Oberried (surface) & OR & $\mathrm{BE}$ & 3.8 & 3.9 & 2.7 \\
\hline Grubenwald (surface) & GW & $\mathrm{BE}$ & 6.7 & 7.4 & 6.0 \\
\hline Siebenbrunnen (karst) & SB & $\mathrm{BE}$ & 0.1 & 0.2 & 0.2 \\
\hline Retzliberg (karst) & $\mathrm{R}$ & $\mathrm{BE}$ & - & 0.5 & 0.4 \\
\hline Loquesse (karst) & $\mathrm{L}$ & VS & 0.4 & - & - \\
\hline
\end{tabular}

${ }^{a}$ Uncertainty was estimated with six different integration methods to compute loading as described in Hugentobler (2013).

$\mathrm{b}$ Mean flow velocity was computed from the time delay between injection and first tracer arrival at locations, accounting

for elevation differences in underground flow paths and visible surface flow paths as described in Hugentobler (2013).

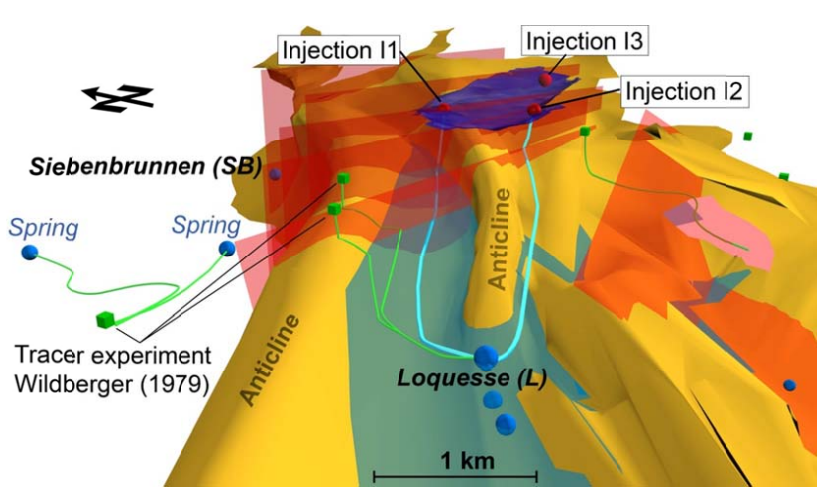

Fig. 3. Visualization of possible meltwater flow paths through the karst below Glacier de la Plaine Morte. Red and transparent planes are faults. Tracing experiments carried out by Wildberger in 1979 are represented in green, including the expected underground flow paths. The Glacier de la Plaine Morte is visible in the middle (dark blue). Blue spheres are karstic springs. The blue surfaces with some transparency are karstic nappes. The two flow paths (light blue) coming from tracer injection points on the glacier are inferred from the available geology.

The first three experiments were carried out simultaneously on 22 August 2011 in order to assess the contribution of ice melt from three representative regions of the glacier to runoff. According to the geologic information assembled in the karst model (Sect. 3.1; Fig. 3), the glacier can be divided into three regions. (i) The northwestern region is expected to drain via the large syncline towards the Loquesse spring. However, the presence of faults cutting the northwestern anticline makes it also possible for water to flow also towards the northwest, to Bernese karst springs. (ii) The central region is expected to drain towards the Loquesse spring through the southern, narrower syncline. A connection to Bernese springs is not probable unless shallow holes along the Trübbach make such a connection possible. (iii) The southern region is expected to drain through a path along the southern syncline to the Loquesse spring. Previous tracer experiments by Crestin (2001) indicate drainage from this region towards the south.

To validate these assumptions $36 \mathrm{~kg}$ eosine, $38.8 \mathrm{~kg} \mathrm{Du}-$ asyn and $12 \mathrm{~kg}$ uranine were added to the meltwater at three locations (I1, I2 and I3) on the glacier. Tracer mass was diluted on site and injected to supraglacial meltwater streams at $\sim 20 \mathrm{~m}$ distance from glacier moulins of more than $50 \mathrm{~m}$ depth. While these tracer amounts seem to be very high for a glacier and surface runoff experiments, it was necessary to use these quantities to explore adequately an unknown karst system of several hundreds of $\mathrm{km}^{2}$. Nevertheless, tracer amounts were significantly reduced during the following injections (Tables 3 and 4) in order to avoid unnecessary stream colorations. The objective of performing three simultaneous tracer experiments was to investigate melt pathways from the northern region of the glacier (represented by I1), the southern region of the glacier (represented by I2) and the southeastern region of the glacier (represented by I3). Accordingly, eosine was injected at a northern location (I1), Duasyn at a southwestern location (I2) and uranine at a southeastern location on the glacier (Fig. 1 and Table 2). In the following three-month water samples were collected at 30 karst springs and surface runoff around the Plaine Morte area. Samples 
were collected at 10 locations with automatic samplers and 20 further locations manually. During the first $42 \mathrm{~h}$ after tracer injections, automatic sampling was conducted with hourly resolution and manual sampling was conducted with $6 \mathrm{~h}$ resolution. In the following seven days, automatic sampling frequency was reduced to $4 \mathrm{~h}$ intervals, while manual sampling was performed every $8 \mathrm{~h}$. Subsequently, the following 11-day automatic sampling was reduced to $6 \mathrm{~h}$ intervals, while manual sampling was reduced to daily samples. Sampling at all automatic sampling location was continued for two months with daily frequency to monitor retarded tracer amounts.

On 6 August 2012 and 2 September 2012, two supplementary tracer experiments were carried out by injecting uranine about $600 \mathrm{~m}$ south of location I2 (Fig. 1c). The objective of these experiments was to investigate the evolution of melt pathways in the glacier before and after intense melting periods.

Tracer concentrations in collected water samples were determined in the lab by initiating the tracer in a LS-5B PerkinElmer luminescence spectrometer. Uranine was illuminated at $490 \mathrm{~nm}$, eosine at $512 \mathrm{~nm}$ and Duasyn at $449 \mathrm{~nm}$. Respectively, emissions from the three tracers were measured at $515 \mathrm{~nm}, 537 \mathrm{~nm}$ and $474 \mathrm{~nm}$. Tracer concentration is directly proportional to the fluorescence emission of the tracer. Fluorescence emission peaks measured in every sample were verified manually based on our in-house year-long proceedings (Wernli, 2011).

\subsection{Isotope measurements}

In order to investigate the provenance of runoff water in karst springs, measurements of isotopic compositions were made on water samples from the test site. For this purpose water samples were collected during the entire melting phase (from June to September) from karst springs on the south slope of the Plaine Morte (Loquesse, Ertèntse and Tièche; Fig. 1c), from meltwater of snow fields and from rain gauges in which local precipitation was collected. The $\mathrm{H}$ - and O-isotope composition was measured using a wavelengthscanned cavity ring down spectroscopy (WS-CRDS) system (Picarro L1102i). The instrument was calibrated before every measurement sequence using three internal standards and normalized on the international scale of VSMOW (Vienna Standard Mean Ocean Water) and SLAP (Coplen, 1994). The uncertainty of the technique lies at $\pm 0.07 \%$ o for O- and $\pm 0.4 \%$ o for $\mathrm{H}$-isotope compositions given on the familiar $\delta$ scale in parts per thousand relative to VSMOW.

\subsection{Glacier melt modeling}

Meltwater runoff and glacier evolution of the Glacier de la Plaine Morte is calculated using the glacio-hydrological model GERM (Huss et al., 2008). The model accounts for the spatial distribution of snow accumulation, snow melting and ice melting, glacier geometry change and evaporation but does not simulate the complex flow pathways required to assess the integrated response of the catchment. The amount of melting is simulated based on an enhanced temperature index model (Hock, 1999) accounting for temporal and spatial variations in potential solar radiation. Glacier geometry change is calculated using a simple parameterization of glacier retreat and measured ice thickness distribution (Huss et al., 2010). The model is run on a $25 \times 25 \mathrm{~m}$ grid at daily resolution and provides runoff components for the entire glacierized area, as well as annually updated ice-covered areas and glacier ice volumes. The glacio-hydrological model thus provides quantities of glacier meltwater but does not simulate the complex pathways of water, and therefore does also not provide the complete drainage basin runoff that could be compared to discharge measurements.

The model is driven using daily mean air temperature and precipitation recorded at an automatic weather station maintained by MeteoSwiss at Crans-Montana and is calibrated using the observed ice volume change of the Plaine Morte. Volume change for the period 1956-2005 is obtained from two digital elevation models that are based on a topographical map and aerial photogrammetry (Bauder et al., 2007). Model results are validated against direct observations of winter snow accumulation at up to 100 measurement sites, and summer ablation at 4 locations on the glacier surface for the hydrological years 2010 to 2012.

In order to provide perspectives on future hydrological impacts of the ongoing glacier retreat, model runs were performed for the period 2010-2100 using climate scenarios forced with the A1B emission scenario. The glaciohydrological model was forced using probabilistic changes in seasonal air temperature and precipitation based on the median of 10 regional climate models for the alpine region (Huss et al., 2010; Frei, 2007).

\section{Results}

\subsection{Meteorological and hydrological observations}

The meteo-, hydrological and snow conditions before, during and after the tracer experiments are of major relevance for interpreting the tracer experiment results (see Sect. 5). The dynamics of snow cover depletion and meltwater pathways strongly depend on local air temperature and precipitation. As the glacier is temperate (i.e., at the pressure-melting point) throughout the entire ice volume, plastic deformation of ice is an important process leading to a relatively rapid closure of empty glacial voids and drainage channels when the water input into the system is reduced (i.e., the channels are no longer supported by water pressure) (Röthlisberger, 1972). On Glacier de la Plaine Morte, this was directly observed in bore holes (M. Schwikowski, personal communication, 2012). 
Table 4. Overview of the tracer recovery in karst and surface runoffs after injections at location I2.

\begin{tabular}{|c|c|c|c|c|c|}
\hline & Abbrev. & & Duasyn & Uranine & Uranine \\
\hline Injection date & & & 22 Aug 2011 (S2) & 6 Aug 2012 (S1) & 2 Sep $2012(\mathrm{~S} 3)$ \\
\hline Mean $T$ at $\mathrm{W} 2\left[{ }^{\circ} \mathrm{C}\right]$ & & & 12.5 & 8.5 & 0.4 \\
\hline Snow height at $\mathrm{W} 1[\mathrm{~cm}]$ & & & 0 & 0 & $\sim 30^{\mathrm{a}}$ \\
\hline Ratio of snow cover area & & & 0 & 0.03 & 0.15 \\
\hline Total injected amount $[\mathrm{kg}]$ & & & 38.4 & 8 & 4 \\
\hline Location (type) & & Canton & & acer recovery $[\mathrm{kg}]^{\mathrm{b}}$ & \\
\hline Oberried (surface) & OR & $\mathrm{BE}$ & $12 \mathrm{~kg}$ & 1.0 & - \\
\hline Grubenwald (surface) & GW & $\mathrm{BE}$ & $8.8 \mathrm{~kg}$ & 1.3 & - \\
\hline Retzliberg (karst) & $\mathrm{R}$ & $\mathrm{BE}$ & traces & - & - \\
\hline Siebenbrunnen (karst) & SB & $\mathrm{BE}$ & traces & $0.01 \pm 0.001$ & - \\
\hline Trübbach (surface) & TB & $\mathrm{BE}$ & - & $0.5 \pm 0.1$ & - \\
\hline \multirow[t]{2}{*}{ Loquesse (karst) } & $\mathrm{L}$ & VS & $12 \mathrm{~kg}$ & $4.5 \pm 0.2$ & $4.4 \pm 0.3$ \\
\hline & & & \multicolumn{3}{|c|}{ Mean flow velocity $\left[\mathrm{km} \mathrm{h}^{-1}\right]^{\mathrm{c}}$} \\
\hline Trübbach (surface) & TB & $\mathrm{BE}$ & 2.3 & 1.6 & - \\
\hline Oberried (surface) & OR & $\mathrm{BE}$ & 3.8 & 3.4 & - \\
\hline Grubenwald (surface) & GW & $\mathrm{BE}$ & 6.6 & 3.8 & - \\
\hline Siebenbrunnen (karst) & SB & $\mathrm{BE}$ & 0.1 & 0.2 & - \\
\hline Loquesse (karst) & $\mathrm{L}$ & VS & 0.3 & 0.5 & 0.2 \\
\hline
\end{tabular}

a On 2 September a snow height of $\sim 30 \mathrm{~cm}$ was recorded; however measurements close to the injection point $\mathrm{I} 2 \mathrm{revealed} \sim 40 \mathrm{~cm}$ of snow heights.

${ }^{b}$ Uncertainties were estimated with six different integration methods to compute loading as described in Hugentobler (2013).

${ }^{c}$ Mean flow velocity was computed from the time delay between injection and first tracer arrival at locations, accounting for elevation differences in underground flow paths and visible surface flow paths as described in Hugentobler (2013).

The evolution of daily mean air temperature and snow height at locations $\mathrm{W} 1, \mathrm{~W} 2$ and CM and average daily discharge into Lac de Tseuzier and in Oberried are illustrated in Fig. 4. Annual mean air temperature between January and September in $\mathrm{CM}$ in 2011 and 2012 were $8.5^{\circ} \mathrm{C}$ and $7.4^{\circ} \mathrm{C}$, respectively (Fig. 4a). Concurrently, mean snow heights at W1 were $88 \mathrm{~cm}$ in 2011 and $127 \mathrm{~cm}$ in 2012. This falls in line with the ratio of snow cover area (SCA) in the watershed derived from satellite images. In 2011 SCA dropped below $50 \%$ by end of March, while in 2012 SCA remained above $50 \%$ until end of April (Fig. 4b). Due to the intense snowfall in 2012, mean discharge between January and September into Lac de Tseuzier and at Oberried increased in 2012 by about $30 \%$ at both locations compared to 2011 (Fig. 4c).

In regard to the interpretation of the tracer experiment results, particular attention should be given to the meteorological conditions just before the tracer experiment. Just before the three simultaneous tracer injections in 2011 (S2 in Fig. 4), air temperature on the Plaine Morte was well above freezing point and the glacier had been snow-free for several weeks. This would represent a condition with intense glacier melt and well-developed melt pathways in the glacier. The date of the tracer experiment performed on 6 August 2012 (S1 in Fig. 4) was the first day the glacier became completely snowfree and an injection was possible. Nevertheless, it was also preceded by a warm period with enhanced snowmelt. The last tracer experiment performed on 2 September 2012 (S3 in Fig. 4) was supposed to represent the conditions at the end of the melting season with very well-developed melt channels in the glacier. However, two days before the injection a cold front arrived, temperatures dropped below freezing and heavy snowfall covered the entire glacier with about $40 \mathrm{~cm}$ of fresh snow.

\subsection{Tracer experiment results}

In the following we first present the results of the three simultaneously performed tracer experiments in August 2011 and then the two complementary tracer experiments performed in August and September 2012 (Table 2).

The objective of the three simultaneously performed tracer experiments with three different tracers injected at three locations on the glacier (Fig. 1c) was to determine melt pathways from three representative regions of the glacier (Sect. 3.3). The observed breakthrough curves at sampling sites are illustrated in Fig. 5. The only locations out of the 30 sampling locations where tracers were detected were the Loquesse spring (location L) in the southwest, the Siebenbrunnen spring in the north (SB), the Retzliberg spring (R) and in Trübbach (TB) and Simme (OR and GW). As shown in Fig. 5, the highest tracer concentrations were detected in the river Simme at OR and GW only a few hours after tracer injections. Indeed, a large amount of glacier runoff drained from the area 


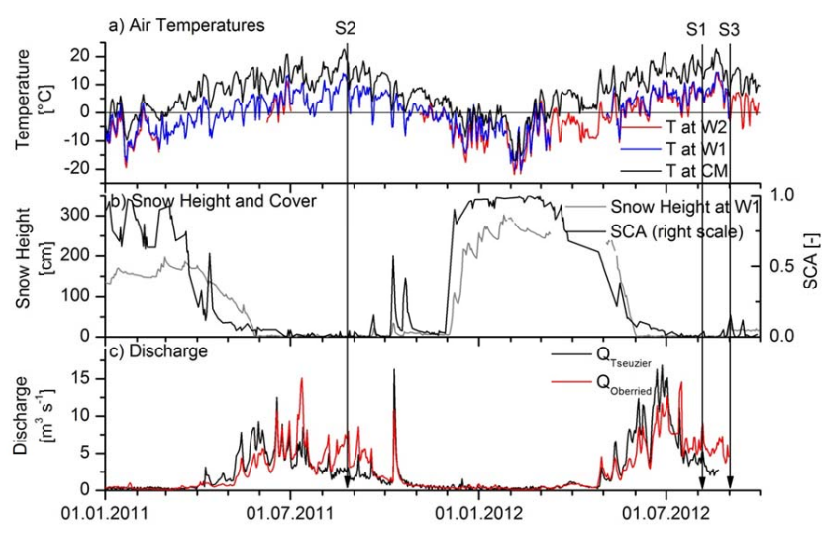

Fig. 4. Hydro-meteorological observations in the region of the Glacier de la Plaine Morte: (a) illustrates mean daily air temperatures at W1, W2 and CM; (b) shows the snow height at W1 and the ratio of snow cover area (SCA) in the entire watershed depicted in Fig. 1; and (c) displays mean daily total discharge into Lac de Tseuzier $\left(Q_{\text {Tseuzier }}\right)$ and at Oberried $\left(Q_{\text {Oberried }}\right)$. S1, S2 and S3 illustrate tracer injection dates.

via the Trübbach, the surface runoff entering into the river Simme. Maximum tracer concentrations were reached a few hours after injections reaching over $850 \mathrm{mg} \mathrm{m}^{-3}$ of eosine, $200 \mathrm{mg} \mathrm{m}^{-3}$ of uranine and $220 \mathrm{mg} \mathrm{m}^{-3}$ of Duasyn. The exact temporal delay between injection and tracer detection at TB is unknown, as sampling frequency in 2011 was too low. Very high concentrations of Duasyn were also recorded at the Loquesse spring, reaching over $200 \mathrm{mg} \mathrm{m}^{-3} 25 \mathrm{~h}$ after injection. Small amounts of uranine and eosine were also recorded at the Siebenbrunnen spring $26 \mathrm{~h}$ after tracer injection. Duasyn was also detected at Siebenbrunnen, but with a delay of $47 \mathrm{~h}$ after injection. Maximum tracer concentrations recorded at Siebenbrunnen were $3.4 \mathrm{mg} \mathrm{m}^{-3}$ of eosine, about $1 \mathrm{mg} \mathrm{m}^{-3}$ of uranine and less than $0.5 \mathrm{mg} \mathrm{m}^{-3}$ of Duasyn. In the small Retzliberg spring, similar concentrations were found, however, first arrival of tracers was almost $12 \mathrm{~h}$ before detection at Siebenbrunnen.

By integrating the product of observed tracer concentration and recorded discharge, the tracer recovery at the different locations can be quantified. All estimated loads are summarized in Table 3. The load estimates indicate that in Grubenwald about $22 \%$ of the injected Duasyn, $82 \%$ of the uranine and the entire amount of eosine were transported into the river Simme during the first 3 days after tracer injection. Very small loads were registered at the karst springs on the Bernese side at Siebenbrunnen and Retzliberg. About $24 \%$ of the injected Duasyn was detected on the Valais side in the Loquesse spring. No tracers were found at all other locations. The tracer loads listed in Table 3 have to be interpreted with caution as load estimates are subject to uncertainties due to low sampling frequency, tracer degradation and uncertainty in discharge estimations.

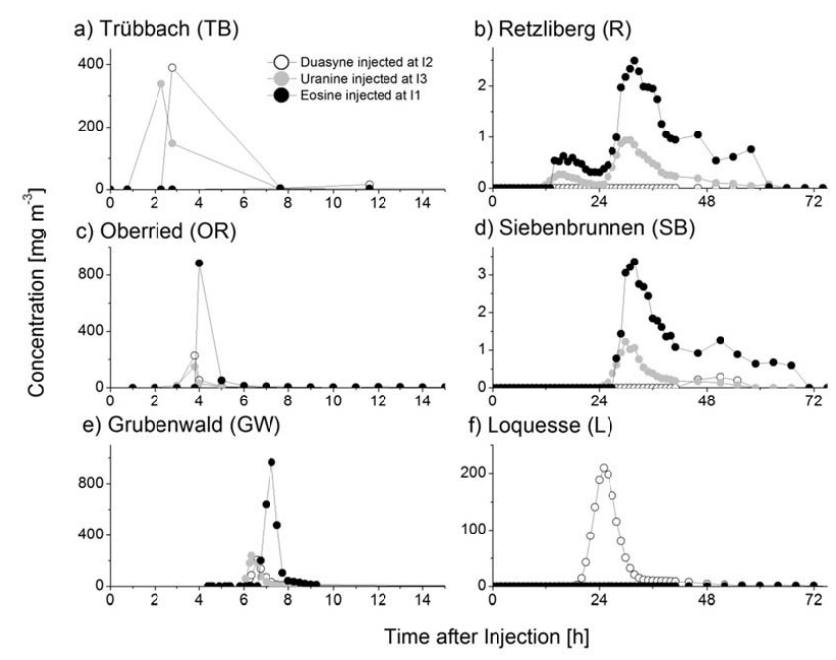

Fig. 5. Tracer breakthrough curves at six sampling sites (TB, OR, GW, R, SB and L) after tracer injection at locations I1, I2 and I3 (see Fig. 1) on Glacier de la Plaine Morte in August 2011.

Mean flow velocities computed from the time delay between injection and first tracer arrival (Hugentobler, 2013) at locations in surface waters indicate velocities of more than $2 \mathrm{~km} \mathrm{~h}^{-1}$ (Table 3). At all karst springs (L, SB and R) the flow velocity was less than $0.4 \mathrm{~km} \mathrm{~h}^{-1}$, falling in line with observations from previous tracer experiments (Wildberger, 1979).

The objective of the two complementary tracer experiments performed in August and September 2012 was to demonstrate how melt paths and glacier discharge patterns evolve over the course of one melting season. The experiments were only performed with uranine, every time injected close to the southwestern location (I2). The injection in 2012 was about $600 \mathrm{~m}$ west of the injection in 2011, which might also have had an impact on the results.

Together with the Duasyn tracer injection in August 2011, tracer breakthrough curves in downstream waters could be assessed for three different situations (S) covering the evolution of melt pathways during an entire melting season: (S1) the injection on 2 August 2012 represents the very start of the ice melting season, as it was performed on the first day the glacier became snow-free and an injection became possible; (S2) the injection on 22 August 2011 represents the period of maximal ice melting as it was preceded by a intense melting period; and (S3) the injection on 6 September 2012 reveals melt pathways after a cold front covered the region with snow. The observed breakthrough curves of these tracer experiments at downstream sampling sites are illustrated in Fig. 6. The breakthrough curves recorded in the surface runoff on the northern side of the glacier (Location $\mathrm{GW}$ ) indicate that travel time between S1 and S2 is similar. In both situations the first arrival time of the tracer was recorded in GW $8.5 \mathrm{~h}$ after the injection. This is reasonable, 


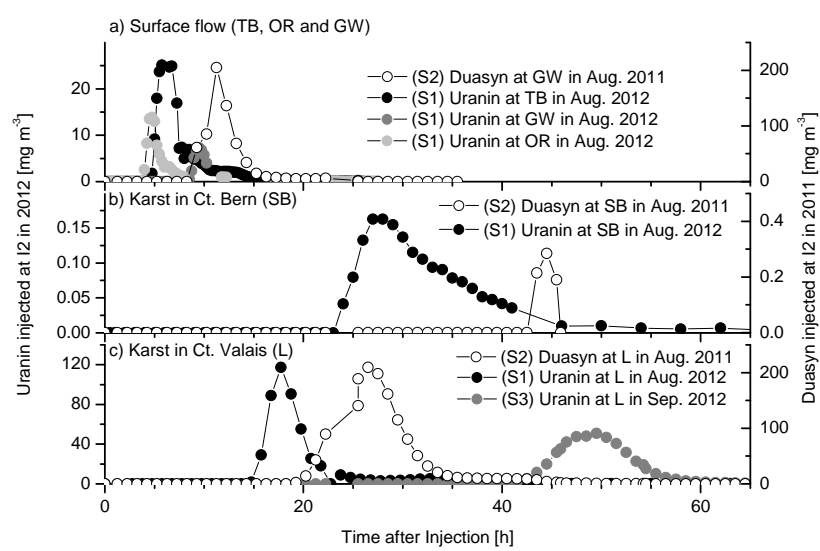

Fig. 6. Tracer breakthrough curves after injection at the southern location (I2) under three distinct meteorological conditions (S1, S2 and S3; Fig. 4): (a) concentrations in surface runoff at TB, OR and GW; (b) concentrations in karstic spring SB on the northern side of the glacier; and (c) concentrations in karstic spring $\mathrm{L}$ on the southern side of the glacier.

as both $\mathrm{S} 1$ and $\mathrm{S} 2$ were preceded by intense melting, and pathways in the glacier leading to the northern surface creek could already be well developed enabling water runoff over the northern surface torrent. The breakthrough curves also reveal that the tracer reached TB and OR after about $4.5 \mathrm{~h}$, confirming the high flow velocities of almost $4 \mathrm{~km} \mathrm{~h}^{-1} \mathrm{ob}$ served in the 2011 experiment (Table 4). During the tracer experiment in September 2012, no tracer could be detected on the Bernese side of the glacier, indicating that residual meltwater in the glacier was reduced and infiltrated into the karst system, as outlined in the Sect. 5.

The breakthrough curve detected in the karst spring SB is illustrated in Fig. 6b. In S1 (experiment in August 2012) the first tracer arrival was already recorded $24 \mathrm{~h}$ after injection, revealing a flow velocity of $0.2 \mathrm{~km} \mathrm{~h}^{-1}$ (Table 4). In S2 (August 2011) the first tracer arrival was only detected at SB $46 \mathrm{~h}$ after injection. Accordingly, the computed flow velocity in S1 is almost twice the flow velocity observed during S2, indicating higher water pressure in S1 increasing the karst through flow. The slightly different injection locations (about $600 \mathrm{~m}$ distance) may also have influenced the flow velocity.

Finally, tracer concentrations detected at the karst spring $\mathrm{L}$ on the southern side of the glacier are illustrated in Fig. 6c. Tracer was detected at $\mathrm{L}$ during all three tracer experiments, making it the only location where the effects of meteo- and hydrological conditions on glacier melt runoff through the karst can be observed. In August 2012 (S1) the tracer was detected $14.75 \mathrm{~h}$ after the injection. In August 2011 (S2) the tracer took 19h to reach L, and in September 2012 (S3) the tracer arrived $40 \mathrm{~h}$ after injection. Accordingly, flow velocities were reduced from $0.5 \mathrm{~km} \mathrm{~h}^{-1}$ (S1) to $0.3 \mathrm{~km} \mathrm{~h}^{-1}$ (S2) and finally to $0.2 \mathrm{~km} \mathrm{~h}^{-1}$ during the melt season (Table 4). This result falls in line with the decrease in flow velocities observed at SB between the injection in August 2012 (S1) and August 2011 (S2). These results support the assumption that with increasing meltwater input, the flow paths in continuous channels in the glacier tend to dominate the karstic system and a higher percentage of runoff flows directly to the surface runoff on the northern side of the glacier. During S1 water reaches the bottom of the glacier, is trapped in the depressions of the glacier basin and percolates into the karst system, while in S2 meltwater is evacuated though the glacier to the surface runoff in the north. Furthermore, the experiment in September 2012 demonstrated that after an onset of winter conditions (S3) the flow paths to the north of the glacier are drastically reduced to local meltwater runoff, and meltwater from the glacial potholes penetrates entirely into the karst.

\subsection{Karst model results}

The results of the tracer experiments were integrated into the 3-D karst model in order to visualize the flow paths of snow and ice meltwater (Fig. 7). The final model demonstrates that most of the water infiltrating the ground in the southern part of the glacier is drained towards the Loquesse spring. However, the northern anticline is traversed by many faults and the geometrical interpretations of the synforms are not the same. The top of the aquiclude is probably not much higher than the groundwater and possibly at the same level at high water conditions in the eastern part. An overflow towards the north (Siebenbrunnen) is therefore possible.

The nature of the karst terrains around the glacier explains why the surface runoff network is poorly developed. The glacier itself lies on karstified limestone, which is probably covered by impermeable lenses of fine sediment of glacial silk. Only in some areas the fine sediment is permeable, allowing water to infiltrate into the karst. This falls in line with observations of Wildberger (1979), who noted that about $50 \%$ of glacier meltwater infiltrates into the karst while the rest is drained at the glacier mouth during high water conditions.

Wildberger (1979) also mentioned the presence of shallow holes in the streambed of the Trübbach allowing part of the discharge to be infiltrated into the karst system shortly downstream of the glacier. This water is expected to reach karst springs on the northern flank (i.e., Siebenbrunnen).

\subsection{Isotopic compositions}

In Fig. 8 the temporal evolution of the isotopic composition measured in karst springs on the southern slopes of the Plaine Morte massif is illustrated. Although the Tièche is sometimes fed with glacier water over the surface runoff, this was not the case during 2011. The striped area in the figure illustrates the range of the isotopic compositions reported from cores taken from the glacier by Schotterer et al. (2004). Results of snow samples collected in spring 2011 indicate that 


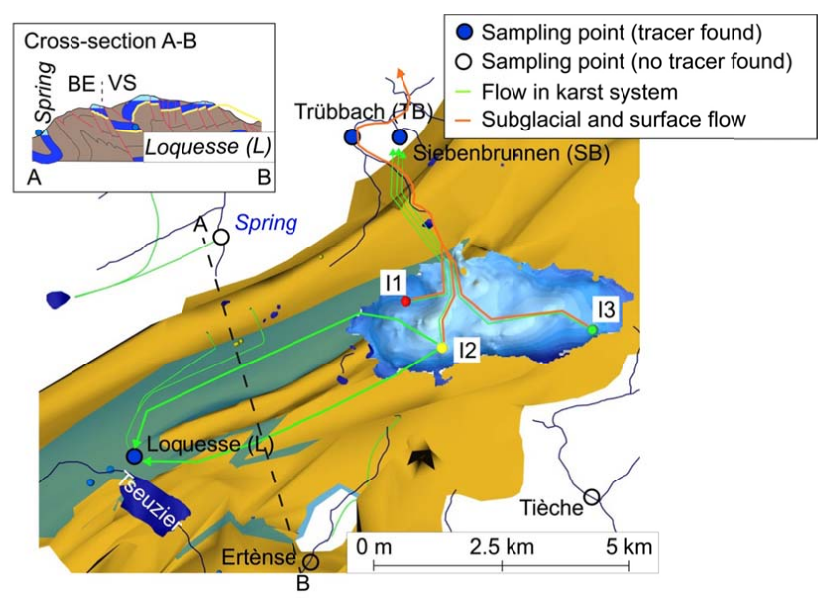

Fig. 7. Visualization of the karst system assembling all data in the karst model. In the upper left corner the cross section shows a yellow layer representing the modeled layer in 3-D. The base of the Plaine Morte glacier is represented with blue shading.

the snowmelt has an isotopic composition that is lower than $-14.5 \%$ in $\delta^{18} \mathrm{O}$ while the isotopic composition measured for precipitation in fall of 2011 had values higher than $-9 \%$ o in $\delta^{18} \mathrm{O}$. The temporal evolution of the isotopic composition in the karst springs south of the Plaine Morte indicates that in spring (May to June) and early July the isotopic composition is compatible with a high contribution of snowmelt. In all three springs the isotopic composition becomes enriched in the heavier isotopes in July, with an isotopic composition similar to that of the glacier as measured by Schotterer et al. (2004). In September the isotopic composition became even more enriched in the heavy isotopes, reaching similar values as measured in typical summer precipitation from the area. This suggests that while the karst springs may have been dominated by glacial meltwater in August, runoff might be dominated in September by local rainfall runoff.

\subsection{Present and future runoff from Glacier de la Plaine Morte}

Daily meltwater runoff determined with the glaciohydrologic model throughout the summer season 2011 indicates that during warm late-summer days more than $7 \mathrm{~m}^{3} \mathrm{~s}^{-1}$ of discharge can be generated by ice melting (Fig. 9). As glacial runoff shows strong diurnal variations (Jansson et al., 2003), maximal runoff in the afternoon is probably significantly above $10 \mathrm{~m}^{3} \mathrm{~s}^{-1}$. The tracer experiments in August 2011 took place during a phase of strong glacier melt. One week of high meltwater input into the glacial drainage system preceded the tracer experiment that took place close to the overall maximum runoff in the year 2011.

Due to the comparably thick ice and the limited surface slopes, the Plaine Morte is expected to show an atypical retreat behavior. Future glacier change is mainly characterized

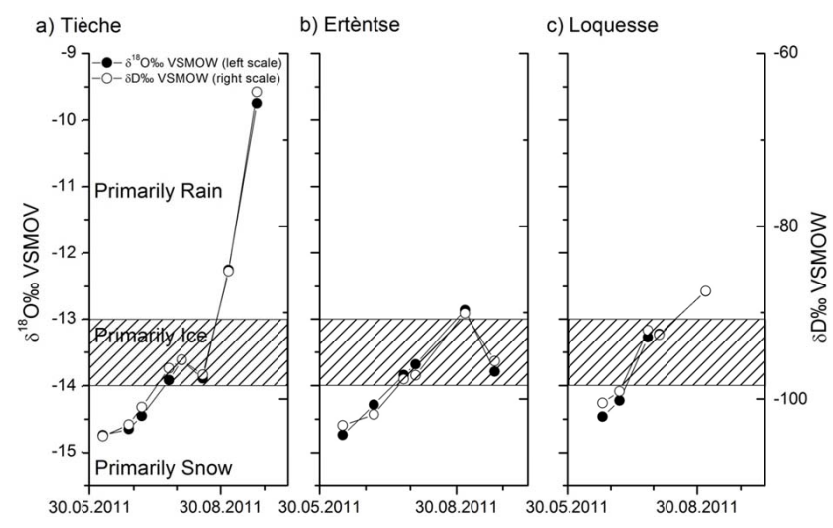

Fig. 8. Temporal development of isotopic composition at selected karst springs south of the Plaine Morte. Typical isotopic signatures found in ice samples are illustrated with striped area. Locations are shown in Fig. 1.

by a strong lowering of the entire glacier surface, but only a limited loss in glacier area over the next decades (Fig. 10). This leads to progressively more negative glacier mass balances due to several positive feedback effects. The climate projections indicate that by 2080 the Plaine Morte will be reduced to a few isolated ice patches. The dynamics of glacier retreat has a significant impact on the runoff from the catchment that is currently occupied by the Plaine Morte. Whereas runoff is expected to increase initially, peaking between 2040 and 2060, due to the release of water from glacial storage, overall basin discharge will decrease below the current level by the end of the century, and it is then dominated primarily by precipitation. The changes in summer runoff are even more important. Whereas runoff is concentrated in July and August at present (almost $60 \%$ of annual runoff), summer runoff from the basin of the Plaine Morte will drastically decrease until 2100 and drop to less than $20 \%$ of the amount found for the first half of the 21 st century.

\section{Discussions}

\subsection{Validation of the karst model}

Results of the tracer experiments reflect well the hypothesis on flow paths formulated before the experiment with the karst model. The three simultaneous tracer experiments in 2011 clearly indicate that glacial meltwater from all regions of the glacier is transferred through the glacier to the surface runoff into the Simmen valley on the northern side of the glacier. This surface runoff is very rapid and reaches mean velocities of up to $3 \mathrm{~km} \mathrm{~h}^{-1}$. The main surprise is the tracer recovery and the flow velocity observed directly below the glacier at Trübbach. The fact that all three tracers were detected within a few hours at the glacier mouth and this without any precipitation occurring over this interval 
a) Daily Melt-Runoff in 2011 and 2012

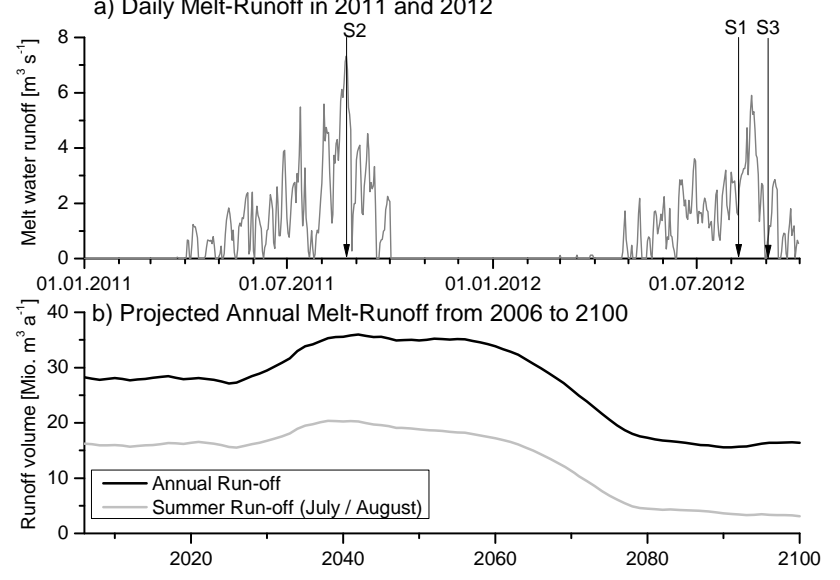

Fig. 9. (a) Calculated meltwater runoff from the surface of the Plaine Morte in 2011 and 2012. The three dates of the tracer injections are illustrated in the figure with an arrow labeled with the according situation. (b) $20 \mathrm{yr}$ running means (annual runoff and the summer runoff) of projected future runoff volume from the basin of the Plaine Morte driven with a median climate change scenario.

implies that, during intense melting, meltwater follows primarily continuous channels through the glacier to the lowest surface runoff Trübbach on the northern side of the glacier. As the bottom topography of the glacier measured by geophysical investigations indicated three depressions (Fig. 10), this can only be the case if the water table within the glacier is high enough to overcome the depression of the glacier basin (Fig. 11a). These findings have to be considered in regard to the extreme weather conditions of 2011. Recordings at the weather station at $\mathrm{CM}$ reveal that air temperature was $2.1^{\circ} \mathrm{C}$ warmer, and 12 more summer days (max temperature exceeding $25^{\circ} \mathrm{C}$ ) were recorded in 2011 than longterm averages. Indeed, the warm temperatures connected with below-average winter accumulation led to strongly neg-

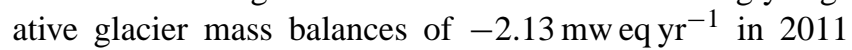
(Voinesco, 2012). In addition, the formation of several ice marginal lakes with a volume of several $100000 \mathrm{~m}^{3}$ was observed (Fig. 1). These lakes drained within hours about one month before the tracer experiment (Hählen, 2012). It can be assumed that the sudden water input of glacier-dammed lakes quickly enlarges channels situated at the ice-bedrock interface by the release of potential energy to the ice (Huss et al., 2007; Bjornsson, 1998). Thus, the lake drainages can actively and efficiently develop the meltwater flow paths within the glacier.

Furthermore, the results from the southern injection point (I2) fit well with the initial hypothesis. In both karstic springs, the Loquesse spring in the southwest and the Siebenbrunnen spring in the north, a tracer recovery of about onefifth of the injected tracer was observed. More surprising is the absence of recovery of eosine and uranine in the Loquesse spring. Water from these two points appears to have
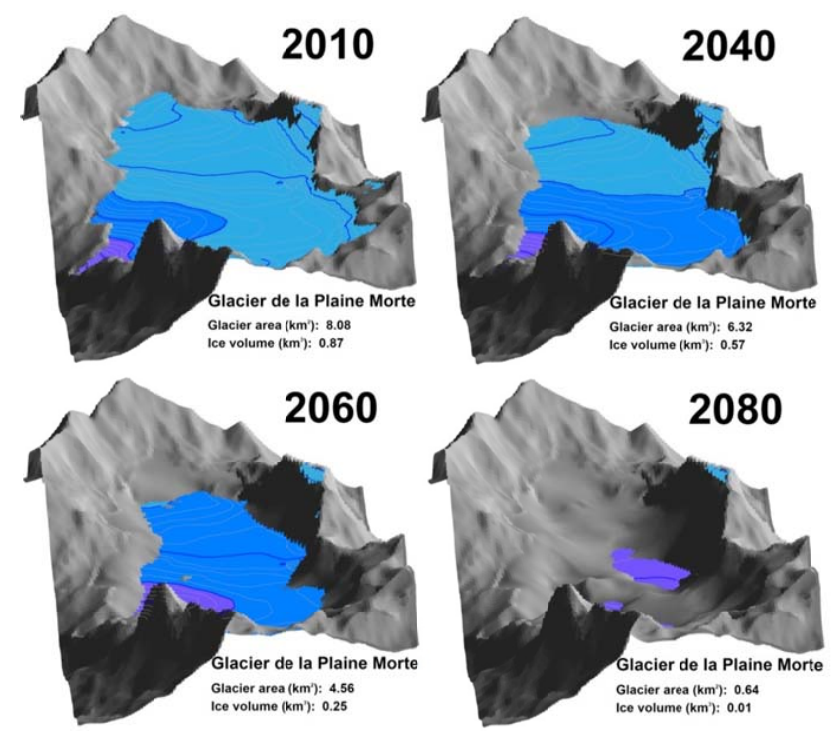

Fig. 10. Modeled future retreat of the Plaine Morte in 2010, 2040, 2060, and 2080. Colors indicate surface elevation bands of the glacier. The glacier area and volume for each time slice are indicated in the panels.

been completely drained by sub-glacial flow and Trübbach, which is rather unexpected from the model as well as from the assessments of Wildberger (1979). Both tracers were found in Siebenbrunnen spring, but this can be related to infiltration of the Trübbach downstream of the glacier rather than to infiltration directly below the glacier. However, the location of the infiltrating sections in the streambed is located south of the top of the anticline in the karst model. It can thus be expected that the upstream part of the northern syncline is drained through faults towards the Bernese springs. Accordingly, it can be argued that the bulk of the glacier melt is drained at the rock-glacier interface towards the north, similarly to observation made at the nearby Tsanfleuron Glacier site (Gremaud and Goldscheider, 2010).

The two supplementary tracer experiments performed in 2012 reveal that the flow paths in the glacier are highly dynamic and evolve during the melting season (Covington et al., 2012). The tracer experiment performed in August 2012, just after the complete disappearance of snow on the glacier surface, revealed that at the beginning of the ice melt season the meltwater also infiltrates into the karst, as a tracer was found within one day in both karst springs SB and L. This was also the case in 2011 when the melt season had been ongoing for several weeks. We tentatively interpret the observations as follows: the subglacial karst is able to take up a given quantity of meltwater, and to evacuate it through the karstic nappes to the south. At the beginning of the melting season and during cold periods, glacial meltwater input is smaller than the potential capacity of the karstic drainage system, and a high percentage of water infiltrates into the karst. During periods with strong glacial meltwater input, as 


\section{a) Summer Period}

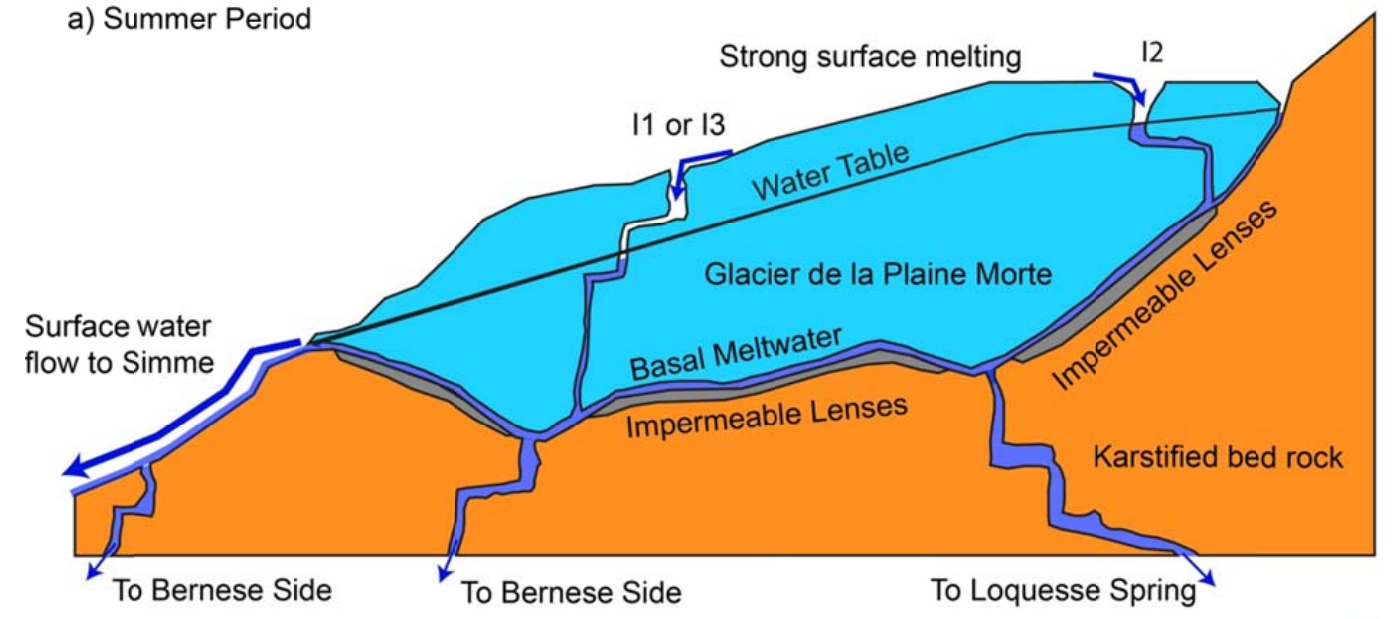

b) Winter Period

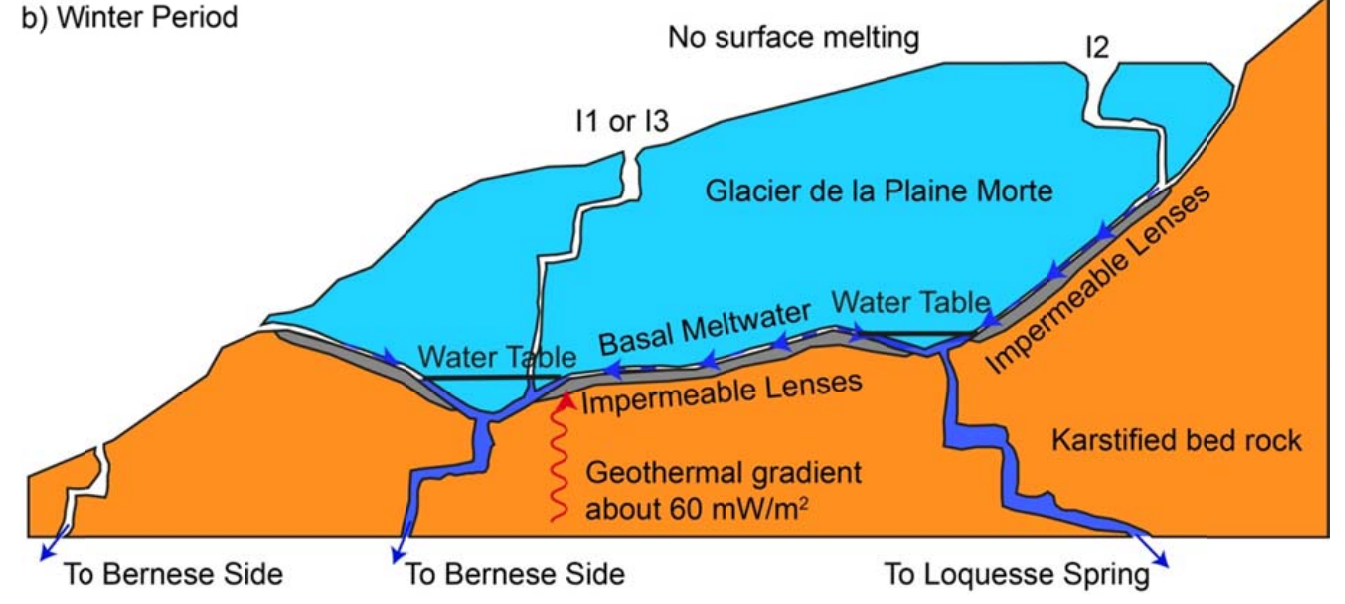

Fig. 11. Schematic sequence of drainage of meltwater in subglacial, karstic and surface flow paths during (a) summer season and (b) winter season.

was the case during the tracer experiment on 22 August 2011, the maximal capacity of the karstic system is reached and the additional water is evacuated in englacial and subglacial pathways following the thalweg. Thus, a high percentage of the meltwater does not infiltrate into the karst in this case (Fig. 11a), but overcomes the topographic depression and drains to the Trübbach in the north. In contrast to the karstic drainage system, channels in the glacier ice can rapidly adapt their diameter, and thus enhance their capacity to an increase in meltwater yield (Iken and Bindschadler, 1986). The glacial drainage system is thus dynamic and is able to transport varying amounts meltwater efficiently, whereas runoff through the static karstic drainage system seems to be limited to a critical upper level. This simple model allows the interpretation of strongly variable percentages of recovered tracer in karstic springs depending on the meteorological conditions. Indeed, the outcome of the last tracer experiment performed in September 2012 is in line with this interpretation. This injection was conducted after a cold front lasting for several days deposited about $40 \mathrm{~cm}$ of snow on the glacier.
Accordingly, ice melting stopped completely during this period, and absolutely no tracer was detected in the surface runoff on the northern side of the glacier (Table 4). Thus, this is an indication that during cold conditions the residual glacial meltwater infiltrates into the karst system and is primarily drained to the Loquesse spring close to Lac de Tseuzier (Fig. 11b).

Furthermore, the results of the tracer experiment indicate that flow under the glacier takes place in continuous channels leading to flow velocities of several $\mathrm{km} \mathrm{h}^{-1}$. This is in line with an observation from the Findelengletscher (Iken and Bindschadler, 1986), where at the beginning of the melt season the glacial water pressure increases leading to an enlargement of the small channels. As glacier channels become larger, flow velocities increase and the amount of meltwater exceeds the uptake capacity of the karst system. Nevertheless, it is expected that the channels at the glacier bottom are changing every year and find their way through the reformed ice and on a very hard loess bed. This means that the amount of water penetrating the underlying karst can be variable (i.e., 
higher at the beginning of the melting season because flow could be partly pressurized and lower when pressure at the glacier bottom becomes lower).

The isotopic compositions observed in water samples collected at the karst sources downstream of the glacier (Fig. 8) support the above-discussed results. The temporal evolution of the isotopic composition in the two karst springs of Loquesse and Ertènse as well as the river sampling site of Tièche are all dominated by snowmelt in spring and early summer. In contrast, once the snow has completely melted, the water in the Loquesse and Ertènse sources is dominated by glacial meltwater. This is in line with the results from the tracer experiments, as breakthrough at the Loquesse source occurred only about 17 to $24 \mathrm{~h}$ after injection, revealing that runoff is dominated by glacial meltwater. Only the river sampling site of the Tièche was dominated in August and September by the ${ }^{18} \mathrm{O}$-enriched rain water, indicating that this site was dominated by surface runoff due to local precipitation.

In summary, the results of the study indicate that during melt season meltwater of the Plaine Morte drains largely towards Trübbach and subsequently to the Simme. Only the southernmost part of the glacier seems to drain clearly to the Loquesse spring, however with an overflow towards Trübbach and Simme. During low flow season the water table in the glacier basin drops and the residual meltwater infiltrates almost entirely into the karst system. In this case the southern part of the glacier is only drained to the southwestern Loquesse spring.

\subsection{Implications of the findings for future water resources}

The simulation of meltwater runoff from the Plaine Morte indicates a highly dynamic water runoff generation in the catchment. The climate change scenarios project an increase of annual and summer runoff until mid-century and then a drastic decrease of net runoff until the end of the century. This is an important conclusion for the water management in the future. Rapid glacier melting during the last years has favored the formation of several marginal glacier lakes around Glacier de la Plaine Morte. The sudden drainage of these lakes represents a serious hazard potential for downstream communities. With intensified ice melting the glacier lakes are expected to increase in volume over the next decades, potentially leading to larger floods. So far, impacts of glacierdammed lake drainages have only been observed on the Bernese side, indicating that during outburst events water flow through the karstic system is not enhanced and flood water is primarily evacuated through fast water flow in subglacial channels. This is consistent with results of the tracer experiment performed on 22 August 2011, a day with strong meltwater input into the system (Fig. 9a); most of the tracer was recovered relatively fast on the Bernese side.
Climate change projections of glacier runoff only account for the glacierized area (Fig. 9b). Accordingly, it cannot be directly compared to observed discharge in downstream rivers. A complete hydrological model to calculate basin runoff including all linkages with the karstic system is beyond the scope of this paper. Nevertheless, the long-term projections until the end of the 21 st century indicate that the glacier is expected to disappear almost completely by the end of the century (Fig. 10). If this is the case, the drainage of snow and ice melt through open channels in the glacier will not be possible anymore, making drainage of snowmelt to the northern surface runoff impossible. Accordingly, downstream water resources will be affected by the loss of glacial meltwater runoff. Furthermore, it can be expected that, in the absence of flow channels in the glacier, meltwater will primarily infiltrate into the local karst and reappear at the numerous karst springs. The tracer experiments indicate that the karst system drains large parts of infiltrating water to the Loquesse spring near Lac Tseuzier. Accordingly, it can be assumed that future meltwater infiltrating into the karst system may be dominantly drained to the Loquesse spring.

In the small karst springs south of Glacier de la Plaine Morte, no florescent tracer was found, indicating that water from the injection points is not drained to those karst springs. Nevertheless, the isotopic signal of the water in these karst springs indicates that during August and September these small karst springs seem to be dominantly fed with glacier meltwater (Fig. 8). An absence of glacier meltwater in these springs could have severe consequences for communities and ecosystems depending on spring water during the summer. Based on the presented results, it is, however, still difficult to quantify the effects of climate change on water resources for these karst springs.

Finally, while the results of our investigations are certainly only valid for the particular study site of Glacier de la Plaine Morte, our interdisciplinary approach leads to an improved process understanding and can be transferred to any other mountainous study site in the world.

\section{Conclusions}

A combination of natural and fluorescent tracer investigations, karst modeling, glacier melt modeling and climate change projections were performed in order to investigate current and future pathways of glacier and snowmelt through the karst below the Glacier de la Plaine Morte in the Bernese Oberland. The results of the tracer experiments and modeling tasks were synthesized in a thorough discussion to give an overview of current and future water resources in the downstream areas of the Plaine Morte. Based on the presented results and the subsequent discussion, the conclusions can be summarized as follows:

1. The results of the tracer experiments indicate that during warm periods in summer most of the meltwater is 
drained through channels at the bottom of Glacier de la Plaine Morte. The observed flow velocities of several $\mathrm{km} \mathrm{h}^{-1}$ suggest that during intense melting periods only a small percentage of the total meltwater flux infiltrates the static karst system, while most of the water follows the thalweg to the north into the surface runoff of the Trübbach. The continuous subglacial channels are formed throughout the summer and are enlarged by high meltwater input into the system, such as glacier lake outbursts, which have repeatedly led to flood waves on the northern side of the Plaine Morte. The results of tracer experiments during cold periods reveal that almost the entire amount of residual meltwater infiltrates into the karst system and drains to the numerous karst springs surrounding the glacier.

2. The isotopic composition in the karst springs around the glacier indicates that karst water is mainly composed of snowmelt in spring, glacier melt in the second half of summer and local precipitation in fall. The fact that only in the three main karst springs fluorescent tracer was found indicates that the smaller karst springs are rather fed by gradual melting in the entire watershed than by point runoff from surface melt of the Glacier de la Plaine Morte. These results are in line with the conclusions obtained from the tracer experiments.

3. Climate change projections indicate that there will be an increase in glacier melt by 2030 to 2050 and a drastic decline by the end of the 21 st century. These projections indicate that the observed rapid runoff during hot summer months will temporarily intensify. Consequently, the risk of glacier lake outburst might increase. As most of the surface meltwater from the Plaine Morte is drained towards Trübbach, the smaller karst springs will very likely not profit from this additional meltwater.

4. By the end of the 21st century, the size of the Plaine Morte will be drastically reduced, decreasing glacier melt to a minimum. This will affect water availability on the north side of the Plaine Morte, which profits currently from the rapid glacier melt. Furthermore, the ionic composition in the karst springs on the southern slopes of the Plaine Morte plateau reveals that these springs are also dominated by glacier melt during the second half of the summer. A reduction of glacier melt will evidently also impact water availability in the glacier-fed karst springs in the south.

5. Overall, it can be concluded that present water availability is not sustainable and that projected future glacier retreat might severely impact water availability in karst springs fed by glacier water during the second half of the summer. Nevertheless, as future precipitation in the area is not expected to decrease, water availability is only expected to decrease due to absence of glacial water in late summer.

Acknowledgements. The present study is part of the MontanAqua project (National Research Programme (NRP) 61). The authors would like to thank the family Allemans, who allowed us to install measuring equipment on their private grounds, and Joël Savioz and Maurice Perraudin from Lienne SA for sampling support and providing discharge data. Furthermore, we express our sincere thanks to the following persons who helped in collecting water samples during the tracer experiments: Jóhannes Torfason, Jan Schwanbeck, Nina Köplin, Carol Hemund, Annette Bachmann, Michael Bühler, Barbara Lustenberger, Flurina Schneider, Mariano Bonriposi, Christine Homewood, Mauro Fischer, Leo Sold, Ueli Schneider, Guido Felder, Emmanuel Rey, Mazzal Stokvis, Michael Lindenmaier, Tilo Schneider, Antoine Marmy, Nicole Glaus, Stefano Bergamaschi, Valentin Zuchuat, Richard Mark, Silvia Hunkeler, Dominique Kröpfli, Gilles Crettaz, Marlène Travelletti and Pascale Blanc. Manuel Nitsche and Abdallah Alaoui provided valuable comments on an earlier version of the manuscript. Finally, we would like to thank C. Leibundgut, M. Bakalowicz, the two anonymous reviewers and Editor B. Schaefli for their valuable comments on an earlier version of this study.

Edited by: B. Schaefli

\section{References}

Badoux, H.: La géologie de la Zone des cols entre la Sarine et le Hahnenmoos, Mat. pour la Carte géol Suisse, 84, 70 pp., 1945.

Bauder, A., Funk, M., and Huss, M.: Ice-volume changes of selected glaciers in the Swiss Alps since the end of the 19th century, in: Annals of Glaciology, Vol. 46, 2007, edited by: Sharp, M., Annals of Glaciology, Int. Glaciological Soc, Cambridge, 145-149, 2007.

Bjornsson, H.: Hydrological characteristics of the drainage system beneath a surging glacier, Nature, 395, 771-774, doi:10.1038/27384, 1998.

Bonacci, O., Jukic, D., and Ljubenkov, I.: Definition of catchment area in karst: case of the rivers Krcic and Krka, Croatia, Hydrolog. Sci. J., 51, 682-699, doi:10.1623/hysj.51.4.682, 2006.

Bühlmann, E.: Influence of particulate matter on observed albedo reductions on Plaine Morte glacier, Swiss Alps, M.Sc. thesis, Paul Scherrer Institute and Oeschger Centre for Climate Change Research, University of Bern, Bern, 97 pp., 2011.

Butscher, C. and Huggenberger, P.: Enhanced vulnerability assessment in karst areas by combining mapping with modeling approaches, Sci. Total Environ., 407, 1153-1163, doi:10.1016/j.scitotenv.2008.09.033, 2009.

Clarke, G. K. C.: Subglacial processes, in: Annual Review of Earth and Planetary Sciences, Annual Review of Earth and Planetary Sciences, Annual Reviews, Palo Alto, 247-276, 2005.

Coplen, T. B.: Reporting of stable hydrogen, carbon, and oxygen isotopic abundances, Pure Appl. Chem., 66, 273-276, doi:10.1351/pac199466020273, 1994. 
Covington, M. D., Banwell, A. F., Gulley, J., Saar, M. O., Willis, I., and Wicks, C. M.: Quantifying the effects of glacier conduit geometry and recharge on proglacial hydrograph form, J. Hydrol., 414, 59-71, doi:10.1016/j.jhydrol.2011.10.027, 2012.

Crestin, G.: Vulnérabilité du milieu karstique de la région de Montana (Valais, Suisse), M.Sc. thesis, Centre d'Hydrogéologie de l'Université de Neuchâtel, Neuchâtel, 2001.

Crook, D. S. and Jones, A. M.: Design principles from traditional mountain irrigation systems (Bisses) in the Valais, Switzerland, Mt. Res. Dev., 19, 79-99, 1999.

Doerfliger, N., Jeannin, P. Y., and Zwahlen, F.: Water vulnerability assessment in karst environments: a new method of defining protection areas using a multi-attribute approach and GIS tools (EPIK method), Environ. Geol., 39, 165-176, 1999.

Dyurgerov, M. B. and Meier, M. F.: Twentieth century climate change: Evidence from small glaciers, P. Natl. Sci. USA, 97, 1406-1411, doi:10.1073/pnas.97.4.1406, 2000.

Farinotti, D., Huss, M., Bauder, A., and Funk, M.: An estimate of the glacier ice volume in the Swiss Alps, Global Planet. Change, 68, 225-231, doi:10.1016/j.gloplacha.2009.05.004, 2009.

Farinotti, D., Usselmann, S., Huss, M., Bauder, A., and Funk, M.: Runoff evolution in the Swiss Alps: projections for selected highalpine catchments based on ENSEMBLES scenarios, Hydrol. Process., 26, 1909-1924, doi:10.1002/hyp.8276, 2012.

Finger, D., Pellicciotti, F., Konz, M., Rimkus, S., and Burlando, P.: The value of glacier mass balance, satellite snow cover images, and hourly discharge for improving the performance of a physically based distributed hydrological model, Water Resour. Res., 47, W07519, doi:10.1029/2010wr009824, 2011.

Finger, D., Heinrich, G., Gobiet, A., and Bauder, A.: Projections of future water resources and their uncertainty in a glacierized catchment in the Swiss Alps and the subsequent effects on hydropower production during the 21 st century, Water Resour. Res., 48, W02521, doi:10.1029/2011wr010733, 2012.

Flowers, G. E., Bjornsson, H., and Palsson, F.: New insights into the subglacial and periglacial hydrology of Vatnajokull, Iceland, from a distributed physical model, J. Glaciol., 49, 257-270, doi:10.3189/172756503781830827, 2003.

FOEN: Auswirkungen der Klimaänderung auf Wasserressourcen und Gewässer. Synthesebericht zum Projekt "Klimaänderung und Hydrologie in der Schweiz (CCHydro), Federal Office for the Environment, Bern, Technical report, 2012.

Frei, C.: Die Klimazukunft der Schweiz. Klimaänderung und die Schweiz 2050 - Erwartete Auswirkungen auf Umwelt, Gesellschaft und Wirtschaft, Beratendes Organ für Fragen der Klimaänderung (OcCC), 12-16, 2007.

Gabus, J. H., Weidmann, M., Sartori, M., and Burri, M.: Sierre Notice explicative, Office fédéral de topographie swisstopo, Bern, 2008.

Gardner, A. S., Moholdt, G., Cogley, J. G., Wouters, B., Arendt, A. A., Wahr, J., Berthier, E., Hock, R., Pfeffer, W. T., Kaser, G., Ligtenberg, S. R. M., Bolch, T., Sharp, M. J., Hagen, J. O., van den Broeke, M. R., and Paul, F.: A reconciled estimate of glacier contributions to sea level rise: 2003 to 2009, Science (New York, N.Y.), 340, 852-857, doi:10.1126/science.1234532, 2013.

Goldscheider, N., Meiman, J., Pronk, M., and Smart, C.: Tracer tests in karst hydrogeology and speleology, Int. J. Speleol., 37, 27-40, 2008.
Grasso, D. A. and Jeannin, P. Y.: A global experimental system approach of karst springs' hydrographs and chemographs, Ground Water, 40, 608-617, doi:10.1111/j.1745-6584.2002.tb02547.x, 2002.

Gremaud, V. and Goldscheider, N.: Geometry and drainage of a retreating glacier overlying and recharging a karst aquifer, Tsanfleuron-Sanetsch, Swiss Alps, Acta Carsologica, 39, 289300, 2010.

Gremaud, V., Goldscheider, N., Savoy, L., Favre, G., and Masson, H.: Geological structure, recharge processes and underground drainage of a glacierised karst aquifer system, Tsanfleuron-Sanetsch, Swiss Alps, Hydrogeol. J., 17, 18331848, doi:10.1007/s10040-009-0485-4, 2009.

Hählen, N.: Strubel-Gletschersee Plaine Morte, Oberingenieurkreis I, Tiefbauamt des Kantons Bern, Gemeinde Lenk, 7, 2012.

Hall, D. K., Riggs, G. A., Salomonson, V. V., DiGirolamo, N. E., and Bayr, K. J.: MODIS snow-cover products, Remote Sens. Environ., 83, 181-194, doi:10.1016/s0034-4257(02)00095-0, 2002.

Hock, R.: A distributed temperature-index ice- and snowmelt model including potential direct solar radiation, J. Glaciol., 45, 101$111,1999$.

Hubbard, B. and Nienow, P.: Alpine subglacial hydrology, Quaternary Sci. Rev., 16, 939-955, doi:10.1016/s0277-3791(97)00031$0,1997$.

Hugentobler, A.: Identifikation von Schmelzwasserfliesswegen in einem karstigen Untergrund mittels fluoreszierenden Tracern. Eine Fallstudie über den Plaine-Morte-Gletscher, M.Sc. thesis, Institute of Geography, University of Berne, Bern, 2013.

Hüsler, F.: A satellite-based snow cover climatology derived from AVHRR data over the European Alps, Ph.D. thesis, Geographisches Institut, Universität Bern, Bern, 175 pp., 2012.

Huss, M., Bauder, A., Werder, M., Funk, M., and Hock, R.: Glacier-dammed lake outburst events of Gornersee, Switzerland, J. Glaciol., 53, 189-200, doi:10.3189/172756507782202784, 2007.

Huss, M., Farinotti, D., Bauder, A., and Funk, M.: Modelling runoff from highly glacierized alpine drainage basins in a changing climate, Hydrol. Process., 22, 3888-3902, doi:10.1002/hyp.7055, 2008.

Huss, M., Jouvet, G., Farinotti, D., and Bauder, A.: Future highmountain hydrology: a new parameterization of glacier retreat, Hydrol. Earth Syst. Sci., 14, 815-829, doi:10.5194/hess-14-8152010, 2010.

Iken, A. and Bindschadler, R. A.: Combined measurements of subglacial water-pressure and surface velocity of Findelengletscher, Switzerland - conclusions about drainage system and sliding mechanism, J. Glaciol., 32, 101-119, 1986.

Jansson, P., Hock, R., and Schneider, T.: The concept of glacier storage: a review, J. Hydrol., 282, 116-129, doi:10.1016/s00221694(03)00258-0, 2003.

Jeannin, P., Eichenberger, U., Sinreich, M., Vouillamoz, J., Malard, A., and Weber, E.: KARSYS: a pragmatic approach to karst hydrogeological system conceptualisation. Assessment of groundwater reserves and resources in Switzerland, Environ. Earth Sci., 69, 999-1013, doi:10.1007/s12665-012-1983-6, 2013.

Jobard, S. and Dzikowski, M.: Evolution of glacial flow and drainage during the ablation season, J. Hydrol., 330, 663-671, doi:10.1016/j.jhydrol.2006.04.031, 2006. 
Kaser, G., Cogley, J. G., Dyurgerov, M. B., Meier, M. F., and Ohmura, A.: Mass balance of glaciers and ice caps: Consensus estimates for 1961-2004, Geophys. Res. Lett., 33, L19501, doi:10.1029/2006g1027511, 2006.

Leibundgut, C.: Tracer experiments in temperate alpine glaciers, in: Tracers in Hydrology, edited by: Leibundgut, C., Malozewski, P., and Külls, C., Wiley-Blackwell, Chichester, UK, 310-321, 2009.

Maire, R.: Les karsts haut-alpins de Platé, du Haut-Giffre et de Suisse Occidentale, Revue de géographie alpine, 65, 403-425, 1977.

Maire, R.: Les karsts sous-glaciaires et leurs relations avec le karst profond, Revue de géographie alpine, 66, 139-148, 1978.

Marechal, J. C., Perrochet, P., and Tacher, L.: Long-term simulations of thermal and hydraulic characteristics in a mountain massif: The Mont Blanc case study, French and Italian Alps, Hydrogeol. J., 7, 341-354, doi:10.1007/s100400050207, 1999.

Pálsson, S.: Draft of a physical, geographical, and historical description of Icelandic ice mountains on the basis of a journey to the most prominent of them in 1792-1794, edited by: Williamsm, R. S. and Sigurdsson, O., Landk-Geology Reykjavik, Iceland, 2004.

Paul, F., Machguth, H., and Kääb, A.: On the impact of glacier albedo under conditions of extreme glacier melt: the summer 2003 in the alps, EARSeL eProceedings, Porto, Portugal, 2005, 139-142, 2005.

Reynard, E.: Gestion patrimoniale et intégrée des ressources en eau dans les stations touristiques de montagne, $\mathrm{PhD}$ thesis, Faculté des Lettres, Université de Lausanne, Lausanne, 509 pp., 2000.

Reynard, E. and Bonriposi, M.: Integrated water use management in dry mountains of Switzerland, The case of Crans-MontansSierre area, International Scientific Conference on Sustainable Development and Ecological Footprint, Sopron, Hungary, 1-6, 2012.

Röthlisberger, H.: Water pressure in intra- and subglacial channels, J. Glaciol., 11, 77-203, 1972.

Schotterer, U., Stichler, W., and Ginot, P.: The Influence of PostDepositional Effects on Ice Core Studies: Examples From the Alps, Andes, and Altai, Earth Paleoenvironments: Records Preserved in Mid- and Low-Latitude Glaciers, edited by: DeWayne Cecil, L., Green, J., and Thompson, L., Developments in Paleoenvironmental Research, Springer Netherlands, 39-59, 2004.
Schuler, T., Fischer, U. H., and Gudmundsson, G. H.: Diurnal variability of subglacial drainage conditions as revealed by tracer experiments, J. Geophys. Res.-Earth Surf., 109, F02008, doi:10.1029/2003jf000082, 2004.

SGHL: Auswirkungen der Klimaänderung auf die Wasserkraftnutzung - Synthesebericht, Schweizerische Gesellschaft für Hydrologie und Limnologie (SGHL) und Hydrologische Kommission (CHy), Bern, 28, 2011.

Siemers, J. and Dreybrodt, W.: Early development of karst aquifers on percolation networks of fractures in limestone, Water Resour. Res., 34, 409-419, doi:10.1029/97wr03218, 1998.

Skoglund, R. O., Lauritzen, S. E., and Gabrovsek, F.: The impact of glacier ice-contact and subglacial hydrochemistry on evolution of maze caves: A modelling approach, J. Hydrol., 388, 157-172, doi:10.1016/j.jhydrol.2010.04.037, 2010.

Smart, C. C.: Hydrology of glacierised alpine karst, $\mathrm{PhD}$ thesis, McMaster University, 343 pp., 1983a.

Smart, C. C.: The hydrology of the Castleguard karst, Columbia, Alberta, Canada, Arct. Alp. Res., 15, 471-486, doi:10.2307/1551234, 1983b.

Smart, C. C.: Statistical evaluation of glacier boreholes as indicators of basal drainage systems, Hydrol. Process., 10, 599-613, doi:10.1002/(sici)1099-1085(199604)10:4<599::aidhyp394>3.0.co;2-8, 1996.

Voinesco, A.: Le glacier de la Plaine-Morte : épaisseur de glace et bilan de masse, M.Sc. thesis, Université de Fribourg, Fribourg, 165 pp., 2012.

Werder, M. A., Loye, A., and Funk, M.: Dye tracing a jokulhlaup: I. Subglacial water transit speed and water-storage mechanism, J. Glaciol., 55, 889-898, 2009.

Wernli, H.-R.: Einführung in die Tracerhydrologie, Geographisches Institut, University of Bern, Bern, 152 pp., 2011.

Wildberger, A.: Beiträge zur Karsthydrologie des Rawil-Gebietes (Helvetische Kalkhochalpen zwischen Wildhorn und Wildstrubel), PhD thesis, Philosophisch-naturwissenschaftliche Fakultät, Universität Bern, Bern, 343 pp., 1979.

Wildberger, A., Jeannin, P., and Pulfer, T.: Hochwasser 1999 und 2000 im Hölloch (Zentralschweiz) Beobachtung und Folgen, Actes du 11 Congrès National de Spéléologie, Genève, Switzerland, 81-88, 2001. 